This is a self-archived version of an original article. This version may differ from the original in pagination and typographic details.

Author(s): Saarinen, Taina; Ala-Vähälä, Timo

Title: Accreditation, the Bologna Process and National Reactions : Accreditation as Concept and Action

Year: 2007

Version: Accepted version (Final draft)

Copyright: @ 2007

Rights: In Copyright

Rights url: http://rightsstatements.org/page//nC/1.0/?language=en

Please cite the original version:

Saarinen, T., \& Ala-Vähälä, T. (2007). Accreditation, the Bologna Process and National Reactions : Accreditation as Concept and Action. Higher Education in Europe, 32(4), 333-345.

https://doi.org/10.1080/03797720802066195 


\title{
ACCREDITATION, THE BOLOGNA PROCESS AND NATIONAL REACTIONS. ACCREDITATION AS CONCEPT AND ACTION
}

\begin{abstract}
The article examines accreditation as a component of the Bologna Process quality policy. The focus is on an analysis of the concept of accreditation in policy documents from four countries (Finland, the Netherlands, France and Sweden). The article focuses on the following questions:

- How does accreditation appear, as a concept and as action, in national reports, produced for the purposes of the Ministerial meetings?

- How is accreditation presented, as a concept and as action, in the national context and for national actors?
\end{abstract}




\section{INTRODUCTION}

The Bologna Process quality policy concentrates currently on the development of comparable quality assurance systems. The participants of the process, represented by their ministries of education, are simultaneously the actors and targets in the process, as they plan the objectives on the European level and are committed to implementing them on the national level.

Accreditation is an interesting special question in the context of quality assurance. The Berlin Communiqué of 2003 presented and the Bergen Communiqué of 2005 further supported the goal of creating national quality assurance systems, which would include "accreditation, certification or comparable procedures". Here, 'accreditation' was brought into European higher education policy through the needs of transferability of degrees and labour policy. The Bologna Process has brought accreditation into European higher education policy in a way that seemed impossible in the 1990s, when any convergence of higher education systems was opposed by European Union member countries (O'Callaghan 1993).

Formally, the Bologna process quality goals appear rather unambiguous as they are represented in the process' own documents. National implementation, on the other hand, seems more problematic. (Stensaker \& Harvey 2006; see also Haug 2003.) Each country works in its own historical context, with national traditions, which naturally leads to different implementations. The same would seem to apply to quality assurance, and accreditation, which is in some countries a relative latecomer in the quality assurance field. We hypothesize that in the Bologna Process quality assurance dimension, there appear to exist two opposite tensions. Firstly, the national systems seem to be converging as accreditation is brought within quality assurance. And secondly, due to national differences in the implementation of the Bologna goals, the concept of accreditation becomes (or remains) fuzzy on the European level.

This article looks into this potential conflict in the meanings and associated definitions and actions attached to the word 'accreditation'. We look 
at "accreditation, certification or comparable procedures" in four different countries: Finland, the Netherlands, France and Sweden.

\section{ACCREDITATION: WORD, DEFINITIONS AND PRACTICES}

The word accreditation has been given various meanings, and it has been defined in different ways. Accreditation comes with various operationalisations, as various actions are attached to it. Also, there exist practices which are not named as accreditation, but which are used in similar contexts. Woodhouse (1999) defines accreditation as the evaluation of whether an institution or a degree can be awarded a particular status. Välimaa (2004) in turn defines accreditation simply as approval based on evaluation. As Kohler (2000) points out, accreditation "smacks of law" in leading to licensing.

In the European context, Westerheijden (2001) refers to the two generations of accreditation, meaning with the first generation the systems implemented in Eastern European HE systems in the early 1990s, and with the second, the accreditation systems ignited by the Bologna process, based on "European transparency". van der Wende and Westerheijden (2001) continue this analysis of accreditation around the themes of transparency and European mobility. Harvey (2004) defines accreditation as focussing either on programmes or institutions. He defines accreditation as "the establishment or restatement of the status, legitimacy or appropriateness of an institution, programme (i.e. composite of modules) or module of study." Harvey also reminds us that accreditation is neither apolitical nor neutral. (Harvey 2004, pp. 207-8).

The use of the word accreditation has political implications in the member countries. The definitions of the word make claims about how it should be used, rather than describe how it is used (see Bacchi 2000, for a further discussion of policy discourse). The definitions of 'accreditation' lead into some kind of operationalisation of it and these operationalisations may vary from country to country, depending on policy needs. In addition, the definitions and practices attached to the concept 'accreditation' construct and steer the higher education policy debate about the quality assurance, and consequently the policy actions related to accreditation. As we hypothesized, the Bologna process may extend the sphere of social action, where accreditation is applied. Thus, the Bologna Process continuously reconstructs and gives new meanings to the concept.

In this article, we look into the appearances of the word accreditation; the meanings attached to it, and the (policy) practices it denotes. In other words, we will analyse, how accreditation appears in the Bologna process

- as a word (What word is used on the national level, what word to report to the European level, about the action attached to accreditation?) 
- as a definition (What kinds of descriptions are given about accreditation or related actions? How is accreditation defined in the documents?)

- as action (What practical actions have been suggested to respond to the demand for accreditation-like procedures in the Bologna process? What kinds of quality assurance related changes have been suggested?)

Our data consist of the following higher education policy documents:

1. Bologna process primary documents (declarations and communiqués)

2. national documents produced specifically for follow-up or reporting purposes of the Bologna process, and directed either for European or national audiences

3. national planning documents from the time before and during the Bologna process

\section{NATIONAL CASES}

An international process such as the Bologna process inevitably brings new impulses to national policies. Policy change is, however, also influenced by national and local contexts. On the one hand, governments demand changes modelled by international examples. On the other hand, similar demands cause different realisations in different national contexts.

The four national cases of Finland, Sweden, France and the Netherlands have been chosen partly based on our previous studies (Ala-Vähälä 2003; AlaVähälä 2005; Saarinen 2005a; Saarinen 2005b). The cases also represent different traditions of higher education in general and quality assurance in particular. The following presents a short review of the development of national Quality Assurance systems; the role of accreditation in QA; and the representation of accreditation in national documents on one hand, and in documents directed for the Bologna process on the other.

\subsection{The Netherlands}

The origins of the Dutch quality assurance policy are from the mid 1980s. The committee report "Hoger onderwijs: autonomie en kwaliteit" (Higher education: autonomy and quality) from 1985 introduced a new ideology of steering. In order to improve governance processes, the "Hoger onderwijs: autonomie en kwaliteit" suggested that the governmental steering should happen at a more general level. The new ideology of steering from remote included two elements: first, the institutions of higher education should have more responsibility for their own work; second, the new system should include an adequate system of quality assurance. (Hoger onderwijs: autonomie en 
kwaliteit, 5-6.) As a result of political debates, a new higher education act covering both universities and polytechnics was accepted in 1993. The system of quality assurance, however, was implemented some years earlier by the associations of universities and polytechnics. In other words, the universities and the polytechnics had separate systems of evaluation. In the system of that time, the educational provision was evaluated discipline by discipline, and each study program in the respective field of education was audited during the evaluation process. In the university sector, these evaluations began in year 1989, and in polytechnics in 1991.

The new policy of quality assurance intended mainly at quality development, which meant that the extern audits did not result any direct sanctions. On the other hand, if the auditors estimated that the quality of education in some study programmes was not sufficient for a higher education institutions, this was mentioned in the report and the auditors gave recommendations about quality improvement. In this case, the study programmes (and their respective universities or polytechnics) had to report to the Inspection of education about their actions with respect to the recommendations. If the institution did not show any improvements, the Government could give sanctions, which as strictest meant, that the government could withdraw the study programme for the list of officially accepted study programmes - which meant that the respective diploma was no more officially recognized. (Jeliazkova \& Westerheijden 2004, 304)

This system of quality assurance was not unanimously accepted by the polytechnics. This is evident from the fact that the actors of the polytechnics sector started to make proposals about a new accreditation based system already in the mid 1990s. The Brouwer commission, which discussed various questions in the field of educational supply of polytechnics, and gave its report in 1995, recommended that each polytechnic study programme having public funding needed to be accredited by an independent organization consisting of representatives from the work environment organisations, association of polytechnics and Ministry of Education and science. (Niet meer maar beter, 64) In the same year, the general meeting of the association of the polytechnics supported this statement. (Het HBO, sterk in ontwikkeling, 21)

After the mid 1990s, the system of accreditation based quality assurance started to develop step by step. In late 1990s the polytechnics started to establish their own master programmes which were not a part of the official degree system at that time. In order to create a system of quality assurance, the polytechnics created a special foundation, Dutch Validation council, which task was to give validations for the new professional master programmes. This protocol was defined as an accreditation. (Masteropleidingen. Brief bestuur HBO-raad, aan de colleges van bestuur/ centrale directies van alle hogescholen. Den Haag 11 maart 1997. See also the D.V.C. Masterregister)

In addition to this, in 1999 the association of the polytechnics, HBO-raad, started piloting the accreditation of existing polytechnic study programmes. This project was called "the experimental accreditation" (proefaccreditering). 
The main motives for the piloting were stated in the instructions for experimental accreditation (protocol proefaccreditering) and in the document "Ten questions about the experimental accreditation" (Tien vragen proefaccreditering). According to them, there was a need for greater objectivity: the system that was now experimented intended at making a clear division between two main functions: first, to validate the basic quality; and second, to support the quality improvement. According to the document "Protocol proefaccreditering", the system of that time mixed these two functions together, resulting in a lack of objectivity. One point of interest is that the evaluation of experimental accreditation, which was carried out in 2002, stated that one main motive behind the piloting project was the need of international transparency in the competitive markets of education. (Goedegebuure \& al. 2002, 5.) This idea of international transparency was not mentioned in the original documents, but after the Bologna declaration it strikes through also here.

The process of establishing the current system of accreditation started in 2000 when the Minister of Education set up a committee in order to discuss the principles of accreditation based system of quality assurance. (Regeling van de minister van Onderwijs, Cultuur en Wetenschappen, nr. WO/B/2000/39880, dd. 6 november 2000, tot instellen van een Commissie Kwartiermakers Accreditatie in het Hoger Onderwijs.) Already in February 2000, the Minister sent a letter establishing the committee, and in the letter gave the reasons for an accreditation based system. The letter mentioned the needs of international transparency, and referred to the Bologna declaration and the need for coordination in the field of quality assurance. At this point, there had been no mention of accreditation in the Bologna Process documentation, and consequently the Minister's letter did not claim that accreditation was demanded by the Bologna process. On the other hand, the letter did present accreditation as a natural answer to the challenges of the Bologna process. According to it, more and more countries recognized accreditation as an instrument for greater transparency and better guarantee for quality.

The committee that discussed accreditation referred to the Bologna Declaration (1999) and to the Prague Communique (2001) and linked the accreditation based system of quality assurance to the Bologna process. Like previous documents, it did not claim that Bologna process required an accreditation based system, but it stated that system based on accreditation had become an common way of meeting the requirements of Bologna process. According to the committee report, many countries were going to introduce an accreditation based quality assurance system in order to guarantee the quality of higher education. (Prikkelen, Presteren, Profileren 2001, 8.)

To sum up, it is evident that the accreditation based quality assurance system started to develop already before the Bologna process. When the Bologna process became a topic of discussion, it was used to legitimate the implementation of an accreditation system. Due to this, it was also natural, that the Dutch government presented the system of accreditation as their response to the Bologna process' requirement of quality assurance. The report prepared 
for the Berlin meeting (Netherlands 2003) talks in detail about the goals and principles of the Netherlands Accreditation Organisation (NAO), which had been founded in 2002. In the report for the Bergen meeting (Netherlands 2005), the change of NAO into the Netherlands - Flemish Accreditation Organisation (NVAO) was reported, together with the new co-operation with the Flemish community in Belgium. In the Bergen report 2005, accreditation is reported widely.

\subsection{France}

In France, there are several quality assurance systems. This article deals with the systems which handle the evaluation of higher education degree programs (habilitation) and the independent evaluation of educational institutions. These systems existed already before the Bologna process, but this process has created some pressures on their development, especially on the system of habilitations. The habilitations of university study programmes have been carried out by the Ministry of Education. In addition, there are separate systems for master level engineering programmes and for economics and business administration programmes. All these habilitations give a status of an official degree - Diplome d'Etat - which means that they have official status guaranteed by the State. The independent evaluations have been carried out by the national evaluation committee CNE (Comité national d'évaluation) and these evaluations have mainly targeted at educational institutions, but CNE has also carried out some discipline based evaluations.

France was one of the initiators of the Bologna Process and one of the four signatories of the Sorbonne Declaration (1998). The report of the Attali Committee from 1999 proposed a three tier study system and a new system of evaluation: each unit was to be evaluated within a certain period, and the evaluations were intended to have an impact on their resources. The committee also proposed a new organisation for evaluation: ASE (Agence supérieure d'Evaluation). Although France soon started to develop a three tier degree system, the system of quality assurance has developed in another direction from the Attali committee's suggestions. Instead of creating a new system and organisation for quality assurance, the Ministry of Education has gradually developed the system of habilitation towards the principles of accreditation. This has implied an essential change from the "ex ante" control of study programmes towards a system of accreditation.

According to Chevaillier, until the mid 1990s the contents of university curricula were stated by the Ministry of Education, and habilitation was a kind of 'conformity check': the Ministry checked that the study programmes followed the principles stated by the Ministry. The contents were checked only once: when the institutions of higher education started their activity and/or when they applied for new study programmes. Since the late 1990s, the 
situation has changed gradually, because the Government has created new types of study programmes without defining a national curriculum for them. Thus, it has become apparent that the approval should be based on expert evaluations instead of "ex ante" regulations. Chevaillier considers that this became absolutely clear in 2002, when the Government decided to renew the degree structure following the Bologna declaration. The Ministry of Education stated that the universities had to make applications for the renewal of all their study programmes. Their only guidance was the criteria that the Ministry would use for its habilitation decision. (Chevaillier, 2004, 160-161) These new habilitations are valid for four years.

As stated above, the habilitations are often presented as a French version of accreditation. (see France 2003; France 2005; cf. Chevaillier 2004). However, the idea of adapting the system of habilitation to the demands of the Bologna process has met with some criticism. The CNE annual report of 2002 states that the system of habilitation is strange for the general public and the level of its transparency is low. (Repères pour l'évaluation 2002, p. 105.) Also, the report of the state auditors considers that the implementation of the common European educational market requires an improvement of the habilitation system. Perez estimates in his article that the system of habilitation is not consistent: a study programme that has established its position, usually gets its habilitation approved, whereas new study programmes may meet stricter evaluation. On the other hand, sometimes new and/or small units of higher education may enjoy positive discrimination. (Perez 2003.)

In addition, the process of habilitation is connected to the four-year cycles of frame work agreements between universities and the government. The process proceeds so that the resource agreements are made before habilitation decisions - this indicates that the Government (or Ministry of Education) has roughly decided about the volume of education in each university already before the habilitation decision. The amount of available resources, in turn, are one criteria of the habilitation decisions. This indicates that political interests, like estimations about local educational needs, strongly affect the habilitation decisions of university degrees. This is stressed by the fact that the habilitation of university study programmes - unlike habilitations of master level engineering programmes and study programmes of economics and business administration - do not include audits (Ala-Vähälä 2005, p. 41, 64)

\subsection{Finland}

In Finland, evaluation became a higher education policy catchword in the 1980's. In the early 1990's the economic recession brought 'quality' to the foreground. Quality was at that time seen as a competitive factor in higher education policy. From the point of view of the academic community, quality 
improvement had to be implemented while resources were cut. (Saarinen 2005a.)

The next episode in Finnish quality policy begun in the mid 1990's as quality assurance begun to be institutionalised in the Finnish higher education system. Assessment became a legal obligation, and the Finnish Higher Education Evaluation Council FINHEEC was founded. Until then, the Ministry of Education had been active in the institutional evaluation experiments. Now the FINHEEC started to take a role as a facilitator of the universities' and polytechnics' self-evaluation practices. The FINHEEC also participated in the licensing of the polytechnics and the accreditation of professional degrees. In other words, the FINHEEC fulfilled different kinds of tasks. By the beginning of the 2000's, quality in Finnish higher education policy had acquired the meaning of development of teaching on one hand and top/quality unit selections on the other. (Saarinen 2005a.)

With the Bologna process, emphasis in Finnish HE evaluation shifted from self-evaluative to quality assurance. Quality assurance has thus far been a relatively irrelevant factor. The BP demands for "accreditation or similar" lead to the development of an audit system which focuses on the quality assurance systems of universities and polytechnics. An interesting detail is that when the audits were first piloted, all piloting institutions were polytechnics, and also in the second round, only one of a total of four was a university. The audits are coordinated by the FINHEEC, which strengthens its role as a channel for Bologna Process quality assurance demands in Finland.

Until very recently, explicit accreditation schemes were not in place, or even discussed. As late as in 2001 it was stated in a Memorandum on the international strategy for higher education (OPM 2001) very clearly that there is no need for accreditation in Finland. The Ministry of Education report for the ministerial meeting in Berlin in 2003 (Finland 2003) on developments in Finland does not mention accreditation at all. The role of FINHEEC is described as facilitative. In the report for Bergen (Finland 2005), accreditation is mentioned in the context of polytechnic's licensing and of professional special degrees. The role of FINHEEC has turned into more active: it is an organiser, evaluator, auditor.

In 2006, however, the Ministry of Education published a memorandum on structural development of higher education (OPM 2006), in which it stated that new educational programmes will be accredited on the basis of their quality and on its need. While accreditation entered Finnish higher education in a fragmented manner, as detailed actions in the polytechnic sector and professional degrees and coordinated by the FINHEEC, it now seems that the Ministry of Education is introducing a comprehensive accreditation system on the programme level (OPM 2006).

In the Finnish higher education field, there seem to emerge different kinds of reactions towards audit. The sluggishness of universities on one hand and the activeness of the polytechnics on the other may have different reasons. This reminds about the Dutch situation, where accreditation begun to be developped 
in the polytechnic sector. On the other hand, the strong role of the Ministry of Education is reminiscent of France. At the moment, however, we do not have the data to pursue these questions further.

\subsection{Sweden}

Sweden is reminiscent of the "government accreditation" also visible in Finland. Right to grant degrees was regulated as stated in the Higher Education Act of 1993, and the rights could be revoked only if certain basic criteria were not fulfilled. Also the applications of university colleges have attained a university status are processed by the Government. The major types of evaluation are institutional audits and programme evaluations. Sweden started audits in 1995, concentrating on the systematic quality work and quality culture on one hand, and programme evaluation on the other. The processes have been "owned" by the National Agency for Higher Education (HSV). (Wahlén 2004.)

The Bologna process has clearly brought pressure also to Sweden when it comes to the development of accreditation or similar procedures. The 2003 report on the advancement of Bologna goals refers to the international professional (i.e. business) accreditation. (Sweden 2003.) The report for Bergen in (Sweden 2005) describes the HSV's assessment procedures, but it also refers to possible changes in the future:

"On the basis of mutual trust and general acceptance of national assurance systems, principles and general standards for quality assurance and accreditation should be developed."

In June 2005, the Swedish Government submitted a proposition for a renewal of higher education, under the title "New World - New University". The main changes dealt with the degree system, and the new degree legislation will take effect in the beginning of 2007. The goals are very much in line with those of the Bologna process: increasing the internationalisation and attractiveness of Swedish higher education, to make the system comparable and understandable internationally, and to increase the quality of the system.

The focus of quality assurance in Sweden has, for the past 5 years, been programme assessment. The final rounds of this programme assessment are under way, and from 2007 a new system will be implemented (HSV 2006a). The proposal for a new system was published in September 2006, and will be decided on in November (HSV 2006b). The proposal covers the years 2007-2012, and it has five components:

1. quality audit of the institutions' quality programmes and their implementation, in a six-year cycle

2. some form of subject and programme reviews 
3. continued accreditation of new programmes for those institutions that do not have the right to grant degrees themselves (this will likely concern mostly the Bologna type two-year masters degrees)

4. thematic evaluations of specific quality aspects (e.g. student affairs and study counselling)

5. evaluation of excellence in teaching and learning

Accreditation is used in Sweden only when colleges apply for university status or when higher education institutions apply for a right to grant (professional or doctoral) degrees, even if several licencing and degree granting procedures could be termed 'accreditation' (HSV 2003.) Current debates on the future of accreditation seem to agree that accreditation should be conducted by an "independent" organization, but at the moment neither professional organisations or the HSV seem to fulfil that requirement (Wahlén 2004).

\section{DISCUSSION: NATIONAL QUALITY ASSURANCE AND THE BOLOGNA PROCESS ACCREDITATION DEMAND}

The uses of the word 'accreditation', its definitions, and the respective policy actions vary clearly from one case county to another. The participants of the Bologna process have been forced, in the context of quality assurance, to react to the demands of creating a system of "accreditation, certification or comparable procedures". As the use of the term 'accreditation' has increased (as the process goals have become more accreditation oriented), the meaning of 'accreditation' has become fuzzier. In addition, there are strong differences in the ways the four countries have put emphasis on the 'accreditation' dimension of the Bologna process.

For instance in the Netherlands, accreditation was planned and decided on before the Bologna process. As the demands for accreditation surfaced in the Bologna process, it was used to support the original, national demands. The Bologna Process is used to legitimate a process which had begun earlier.

Finland appears to be an example of an opposite trend. Before the Bologna process, Finnish (as also Swedish) degree approval processes could be described as "governmental accreditation", which reflects the idea of higher education as a public good. Until the Bergen meeting in 2005, accreditation was either not mentioned or the need for it was explicitly denied in policy documents. Even then, the term was used only in Bologna process reporting to an external audience, and even there only situationally, in the context of licensing polytechnics and granting professional special degrees. Only in 2006 did the term 'accreditation' suddenly appear in Finnish language national documents, in the memorandum on structural development in 2006 (OPM 2006), in the context of accreditation of new programmes. It seems that the 
conceptual content of accreditation has during the Bologna process extended to include audit of quality assurance, which was offered almost euphemistically in Finland to fulfil the role of "accreditation, certification or comparable procedures".

France represents a third way. France was one of the signatories of the Sorbonne Declaration (1998). The reforms ignited there concentrate on developing degree structures. Accreditation is hardly mentioned in the official documents. When it is, it appears in the reports directed at the European process, in the context of naming the habilitation system (dealing with right to award degrees) as 'accreditation' in international contexts.

In Sweden, no system with the name of accreditation has existed. However, the programme-evaluations, which have been conducted every six years, have had a possible sanction of withdrawing the licence to grant degrees. The situation in Sweden is undergoing changes as we speak.

In the beginning of this article we hypothesized that the term 'accreditation' is fuzzy in that, on one hand, national systems appear to converge towards similar terminology, but on the other hand, the definitions and operational contents of 'accreditation' become (or remain) blurry. This seems to be supported by at least the following observations.

Firstly, the term 'accreditation' is introduced differently in our case countries. In the Netherlands, where accreditation has been a policy goal quite early, the term has been adapted in a systematic manner. In Finland and in Sweden, the adaptation has been more fragmented, starting in international contexts from smaller elements of quality assurance and in national contexts mostly outside QA. In France, the term 'accreditation' was introduced relatively early in international contexts, but in the national context the old terminology of habilitation has prevailed.

Secondly, the ways in which the term 'accreditation' is linked to a particular policy action vary, not only between the case countries, but sometimes also within one country, depending on whether the context is national or international. The use of terminology and the policy actions tied to these terms also suggests that the meaning of 'accreditation' is varied. In the Netherlands, the term 'accreditation' is used both nationally and in European documents to refer to the same function. In France, the mostly Ministry-driven (with the exception of engineering and economics and business administration) action of accepting degree programmes is called habilitation in the national context but accreditation in Bologna process reporting. In Finland the term 'accreditation' has not been used nationally until the year 2006, and in Bologna reports the term has been used to describe some isolated instances of polytechnic and special professional degree licensing, which have not been termed as 'accreditation' nationally. Also in Sweden, the term 'accreditation' has not been in consistent national use, but in the Bologna reporting, it has been used to refer to some professional evaluations.

Thirdly, there are differences in the level of practical quality assurance procedures, as the role of an independent expert-auditor / evaluator varies 
from country to country. In the Netherlands, the accreditation is based on the report of independent auditors. In France, on the other hand, the CNE does conduct independent evaluations, but the habilitation process (termed 'accreditation' for the European reader) is controlled by the Ministry of Education, and no audit is included. In Finland, the right to grant degrees has traditionally been given by the State, and no evaluation or audit has been included in the process. The audits if quality assurance systems have, on the other hand, been coordinated by the FINHEEC, but they do not have a licencing function. However, in 2008 things are expected to change, as the Ministry has declared that a system of programme accreditation will be implemented. In Sweden, the HSV acts as an independent evaluator, but its independence has been questioned, and the system is to undergo changes. 


\section{CONCLUSIONS}

Although the participants of the Bologna process share some common targets, they also have to implement them in different national contexts, with different national characteristics and historical backgrounds. As a result, each Ministry of Education studied here appears to give its own interpretation of the Bologna process. In some cases the national level policy documents also depict the development of their quality assurance system in a slightly different way, depending on whether the document is intended for a national or a European reader. Thus, an analysis of the documents in question seems to confirm our original hypothesis.

The conclusions, thus, are:

- In all the countries, policy changes regarding quality assurance in general and accreditation in particular have been implemented.

- In all the countries, the starting points (the existing situations) have been different.

- In all cases, different terminology is used nationally (akkreditointi, habilitaatio, audit, utvärdering)

- In all cases, different actions have been implemented.

The goals of the Bologna Process appear uniform in the documents, but as the demands are taken to the national level, new pressures are placed on them. It remains to be seen, whether this recontextualisation (Wodak 2005) of a transnational policy is a permanent or a temporary phenomenon. The apparently similar QA goals may be presented in different ways, depending on national policy needs. Changes in policy structures do not necessarily mean that changes in policy processes would take place. Further research in the national and local levels is needed in order to see, what happens when the policies hit the departments. In any case, the consequences of a uniform demand are not uniform. 


\section{REFERENCES}

Ala-Vähälä, T. 2003. Hollannin peili. Ammattikorkeakoulujen master-tutkinnot ja laadunvarmistus. Helsinki: Korkeakoulujen arviointineuvosto.

Ala-Vähälä, T. 2005. Korkeakoulutuksen ulkoisen laadunvarmistuksen järjestelmät Ranskassa. Helsinki: Korkeakoulujen arviointineuvosto.

Attali J. \& al. 1999. Pour un modèle européen d'enseignement supérieur. Rapport de la Commission Jacques Attali. Retrieved September 28, 2006 from www.education.gouv.fr/forum/attali.htm.

Bacchi, C. 2000. Policy as discourse: what does it mean? where does it get us? Discourse: studies in the cultural politics of education 21 (1), 45-57.

Bologna declaration 1999. The European Higher Education Area. Joint declaration of the European ministers of education. Convened in Bologna on the 19th of June 1999.

Chevaillier, T. 2004. Country report France. In S. Schwarz and D. Westerheijden (Eds.) Accreditation and evaluation in the European Higher Education Area. Frankfurt: GEW, 149-162.

D.V.C. Masterregister 2000. Manual for the registration and accreditation of Master degree courses. 2de editie. Dutch Validation Council.

Finland 2003. National report for the Berlin meeting. Bologna follow-up. Helsinki: Ministry of Education.

Finland 2005. National report for the Bergen meeting. Bologna follow-up. Helsinki: Ministry of Education.

France 2003. National report for the Berlin meeting. Bologna follow-up.

France 2005. National report for the Bergen meeting. Bologna follow-up.

Goedegebuure, L. et al. 2002. Alle begin is moeilijk. Evalutie van de proefaccreditering HBO. Enschede: Uniwersiteit Twente.

Harvey, L. 2004. The Power of accreditation: views of academics. Journal of Higher Education Policy and Management 26 (2), 207-223.

Haug, G. 2003. Quality assurance / accreditation in the emerging European Area of Higher Education: a possible scenario for the future. European Journal of Education 38 (3), 229-240.

Het HBO, sterk in Ontwikkeling. 1995. Het standpunt van de hogescholen in het devat over het stelsel van hoger onderwijs. Den Haag: HBO-raad.

Hoger onderwijs: autonomie en kwaliteit. 1985. Tweede Kamer der StatenGeneraal Vergaderjaar 1985-1986, 19 253, nr 2.

HSV 2003. Ackreditering - en öppen fråga. Högskoleverkets rapportserie 2003:4 R. Stockholm: Högskoleverket.

HSV 2006a. How did things turn out? Quality evaluations 2005. Högskoleverkets rapportserie 2006:33 R. Stockholm: Högskoleverket. Retrieved September 14, 2006, from http://www.hsv.se/.

HSV 2006b. Information on the new quality assurance system. Stockholm: Högskoleverket. Retrieved September 14, 2006, from http:/ / www.hsv.se/. 
Jeliazkova, M. \& Westerheijden, D. 2004. Country report The Netherlands. In S. Schwarz \& D. Westerheijden (Eds.) Accreditation and evaluation in the European Higher Education Area. Frankfurt: GEW, 299 - 315.

Kohler, J. 2003. Quality assurance, accreditation, and recognition of qualifications as regulatory mechanisms in the European Higher Education Area. Higher Education in Europe 28 (3), 317-330.

Masteropleidingen 1997. Brief bestuur HBO-raad, aan de colleges van bestuur/ centrale directies van alle hogescholen. Den Haag 11 maart 1997. Hogeschoolbericht 209, April, 1997.

Netherlands 2003. National report for the Berlin meeting. Bologna follow-up.

Netherlands 2005. National report for the Bergen meeting. Bologna follow-up.

Niet meer naar beter 1995. Eindrapport Commissie Referentiekader Onderwijsaanbod. 's-Gravenhage: HBO-raad.

O'Callaghan, D.F. 1993. Synthesis of principal responses to the memorandum. In The outlook for higher education in the European Community. Responses to the Memorandum. Task Force Human Resources, Education, Training and Youth. Studies 2. Bruxelles, Commission of the European Communities, 27-57.

OPM 2001. An international strategy for higher education. Helsinki: Ministry of Education.

OPM 2006. Korkeakoulujen rakenteellisen kehittämisen periaatteet. Discussion papers of the Ministry of Education 2006:2. Helsinki: Ministry of Education. [Principles of structural development of higher education].

Perez, R. 2003. Les procédures d'accréditation-évaluation dans le système universitaire français: dispositif et impact. Paper presented at The International Colloquium Accreditation and Quality, A new strategy for the European University?, Alcana de Henarez, Spain, 2003.

Prague Communique 2001. Towards the European Higher Education Area. Communique of the meeting of European ministers in charge of Higher Education in Prague on May 19th, 2001.

Prikkelen, Prestieren, Profilieren 2001. Commissie accreditatie hoger onderwijs. Eindrapport. Amsterdam: Van de Bunt.

Protocol proefaccreditering 1999. Den Haag: HBO-raad.

Regeling van de minister van Onderwijs, Cultuur en Wetenschappen, nr. WO/B/2000/39880, dd. 6 november 2000, tot instellen van een Commissie Kwartiermakers Accreditatie in het Hoger Onderwijs, in Prikkelen, Prestieren, Profilieren. Commissie Accreditatie Hoger Onderwijs. Eindrapport. Bijlage 1. Amsterdam: Van de Bunt.

Repères pour l'évaluation 2002. Rapport au president de la République. Commité national d'évaluation. La documentation Française.

Repères et references 2004. Repères et références statistiques sur les enseignements, la formation et la recherche - édition 2004. Ministère de l'Éducation nationale, de l'Enseignement supérieur et de la Recherche, Direction de l'évaluation et de la prospective. 
Saarinen, T. 2005a. From sickness to cure and further. Construction of 'quality' in Finnish higher education policy from the 1960's to the era of the Bologna process. Quality in Higher Education 11 (1), 3-15.

Saarinen, T. 2005b. 'Quality' in the Bologna process: from 'competitive edge' to quality assurance techniques. European Journal of Education 40 (2), 189204.

Sorbonne Declaration 1998. Joint declaration on harmonisation of the architecture of the European higher education system by the four Ministers in charge for France, Germany, Italy and the United Kingdom. Paris, the Sorbonne, May 25, 1998.

Stensaker, B. \& Harvey, L. 2006. Old wine in new bottles? A comparison of public and private accreditation schemes in higher education. Higher Education Policy 19 (1), 65-85.

Sweden 2003. National report for the Berlin meeting. Bologna follow-up.

Sweden 2005. National report for the Bergen meeting. Bologna follow-up.

Tien vragen over proefaccreditering 2001. Algemene informationbrochure. Den Haag: Bureau HBO-raad.

Välimaa, J. 2004. Three rounds of Evaluation and the idea of accreditation in Finnish higher education. In S. Schwarz \& D. Westerheijden (Eds.) Accreditation and evaluation in the European Higher Education Area. Dordrecht: Kluwer, 101-125.

van der Wende, M. \& Westerheijden, D. 2001. International aspects of quality assurance with a special focus on quality in higher education. Quality in Higher Education 7 (3), 233-245.

Wahlen, S. 2004. Country report Sweden. In S. Schwarz and D. Westerheijden (Eds.) Accreditation and evaluation in the European Higher Education Area. Frankfurt: GEW, 395-410.

Westerheijden, D. 2001. Ex Oriente lux? National and multiple accreditation in Europe after the fall of the Wall and after Bologna. Quality in Higher Education 7 (1), 65-75.

Woodhouse, D. 1999. Quality and quality assurance. In Quality and internationalisation in higher education. Paris: OECD, 29-44. 